\title{
The Application on EPC in Project Management of Industrialized Buildings
}

\author{
Yingbo $\mathrm{Ji}^{1, \text { a }}$, Yiwei Wang ${ }^{1, \mathrm{~b}}$, Jianyong $\mathrm{Lu}^{1, \mathrm{c}}$ and Xiaoshan Wang ${ }^{1, \mathrm{~d}}$ \\ ${ }^{1}$ North China University of Technology, China \\ ajiyingbo@126.com, b1367742386@qq.com, ${ }^{\mathrm{c}} 1160967389 @ q q . c o m,{ }^{\mathrm{d}} 1498923423 @ q q . c o m$
}

Keywords: industrialized building; construction industrialization; EPC; management integration; technology integration

\begin{abstract}
Based on analyzing the basic characteristics and management situation of the mode for construction industrialization organization, the advantages of Engineering Procurement Construction (EPC) applied on project management of the industrialized buildings were discussed. During the process, organization optimization, process optimization and information integration are used in application of EPC in the project management for industrialized buildings. An EPC management model is established which is adapted to industrialized buildings. Meanwhile the existing problems of application in the industrialized buildings are analyzed and the solutions are proposed.
\end{abstract}

\section{Introduction}

New-type construction industrialization is characterized by its design standardization, component produced in factory, component assembled on site, management informatization and decorate integration ${ }^{[1]}$. It is a sustainable production method which can integrate the whole industry chain of design, produce and construct and realize the maximization in energy-saving, environmental protection and life cycle value. Since it is totally different from traditional building, the traditional mode is no more suitable in the industrialized building. A new project management mode is in great need to meet the production in industrialized buildings.

\section{The Characteristics of Construction Industrialization}

The characteristics of construction industrialization can be classified into the following parts according to different stages:

\section{1) Design Phase}

Design standardization: the relationships among different phases in industrialized buildings are tight and the professional cooperation is more important in design phase than other phase. Design standardization improves the generality of components and the precision of design, further makes it convenient to finish the production and assemblage, shortens the construction time and makes the project management in industrialized buildings systemic.

\section{2) Production Phase}

Component produced in factory is the main phase in industrialized building. The mass wet work on site in traditional construction mode can be transferred into factory. The labor is replaced by machinery to produce components, improve production efficiency and dimensional precision. The factory becomes important in project management. Due to the high cost of component rework, the traditional method of quality management which is accepted after the project is not applicable, and the process control is the key point in the control of components' quality.

\section{3) Assembling Phase}

Assembling on site has the advantages of less work 、 quick installation, but the professional ability of installation workers are required more. Controlling components precision and design standardization is helpful to the assembling. The way of assembly, transportation, hoisting and joints connection become the main contents in the construction management on site. 


\section{4) Decoration Phase}

Decoration integration is the main characteristic in decoration phase. Decoration engineering and the design and construction of the main structure are carried out simultaneously. The objective is to realize the integration between decoration and main structure and avoid the damage to the main structure of building.

\section{5) Operation and Management Phase}

Management informatization in different phases. The application of information technology are required more since the design standardization, component produced in factory and assembled on site in industrialized buildings. The whole process can be covered by the application of information technology, including establishing information model in early, optimizing blueprints in design phase, tracking and recognizing standard units, assemblage simulation, building the communication platform and so on. The main purpose of management informatization is to solve the communication hinder, coordinate the conflicts among different tissues, promote the integration of various advantages and optimize resource allocation.

\section{The Shortages of Traditional Project Management}

The basic characteristic of traditional project management is only the last phase finished when the next phase begins, and the contracts are issued by different phase. The basic contradictions from construction industrialization is showed by following parts:

1) The contradiction exists between the inconsistency of traditional management in construction project and the integration of design and construction in industrialized building. In the traditional project management, there are different managers in design, construction and operation phase due to its separated bids in different phases. In addition, because of the interface connections exist in different phases, the whole management process is divided into separate parts. But for the mode of industrialized building production, the activities in design has significant effects of controlling and guiding on the following activities, which requires strong consistency on the management activities.

2 ) The contradiction exists between the relatively independent management activities in different phases under traditional management and the requirements of life cycle value management in industrialized buildings. For now, the managers in different phases of traditional project management have little idea of life cycle value. The relatively independent of management inclined the managers in different phases to pursue the project management targets of their own companies and the managers can't analyze the total life cycle of a project, consequently the targets of life cycle value management can't be reached.

Table1 The basic contradictions between traditional project management and the production mode of industrialized building

\begin{tabular}{c|c}
\hline traditional project management & The requirements of industrialized buildings \\
\hline the inconsistency management in different phases & design and construction integration \\
\hline $\begin{array}{c}\text { the relatively independent management among } \\
\text { different participants }\end{array}$ & life cycle value management \\
\hline "Information island" & management informatization \\
\hline
\end{tabular}

Thus, the traditional mode of project management does not meet the needs now and we are in eagerly needed to find a more suitable management. It inevitably brings us to the issues of how to connect different phases more successfully, how to make the participants do their jobs in terms of the whole management process and how to achieve the goal of information management.

\section{Make Reference to the development of management in manufacturing industry}

The production of super-sized equipment in manufacture, take shipbuilding as an example. The shipbuilding is a typical method of order pulling production and it has the characteristics of one-piece 
and no pipeline which are similar to construction industry. Its successful development makes reference to the construction industrialization.

The modern shipbuilding mode takes the theory of plan as a whole and optimizing for guidance, uses the group technology principal and takes the intermediate product for guidance, organizes the produce by regional, shells, fixes and paints on the basis of space and time, realizes the design, production and management integration, assembles ship manufacturing equilibrium and continuous. Concretely speaking, modern shipbuilding mode is a production and construction process of modularization and assembly based on components standardization and unitization which is the typical embodies of integrated manufacturing ${ }^{[2]}$.

"Integrated manufacturing system" is an industrial organization system in modern manufacturing industry. It can be concluded into three basic integration processes: system integration, organization integration and information integration. System integration coordinates the whole technological process; organization integration coordinates the whole management mode; information integration makes the communication quickly and comprehensive and ensures the realization of system integration and organization integration. The main characteristic of this production organizational mode is the socialization and integration of production process ${ }^{[3]}$.

\section{Analysis on the applicability of EPC in industrialized buildings}

\subsection{The conception and characteristics of EPC}

EPC is the abbreviation of Engineering, Procurement and Construction. It means the owner principals the total job which includes design, purchase, construction and test-run to one general contractors. It is a project management mode which the general contractor is fully responsible for the quality, safety, construction period and cost.

Table2 The Advantages of EPC

\begin{tabular}{c|c}
\hline Scope of application & Main characteristics \\
\hline $\begin{array}{c}\text { high requirements on the } \\
\text { professional technique }\end{array}$ & $\begin{array}{c}\text { design/purchase/construction integration, design includes } \\
\text { preliminary design and detail design }\end{array}$ \\
\hline difficult to manage & the economic efficiency is high \\
\hline large purchase & clear responsibilities \\
\hline $\begin{array}{c}\text { the owner hopes the contractor } \\
\text { takes more risks }\end{array}$ & the general contractor takes almost all risks \\
\hline
\end{tabular}

\subsection{The advantages of EPC}

1) It can realize the leading role of design. EPC integretes design、construction and purchase since design phase, takes the advantages of design, purchase and construction integration, integrates the project resources, realizes the seamless connection between different phases, makes it easier to control the progress and investment and implement the best comprehensive management ${ }^{[4]}$.

2 ) It is convenient to coordinate the tissues. In the mode of EPC, the coordination and communication among different tissues are established inside and it decreased the communication hinder among different managers which is benefit to the interior digestion of target conflicts. In addition, the application of EPC avoids a overstaffed organization in traditional project department, optimizes the allocation of labors as much as possible and reduces the amounts of managers.

3 ) It helps to reach the life cycle target. The owner provides the finial target since there is only one general contractor and the low participation of owners. So the project is directly related to the control of the EPC general contractor. The EPC emphasizes the importance of setting project targets during the formal planning. In addition, the contracting mode of EPC develops the characteristics of benefit and risk sharing among general contractor 、 design organizations and construction companies. So in the mode of EPC, the whole benefits of the project during the management process are paid more attention and it is benefit to reach the life cycle targets. 


\section{Analysis on the application of EPC in industrialized buildings}

\subsection{Optimizing the application of EPC in industrialized buildings \\ 5.1.1 Organization optimization}

Project organization is the executor of project management and effective organization form is the basis of management integration.

A matrix organization structure of integrated management in industrialized buildings is designed based on the characteristics of industrial construction project management. It makes the structure, power and responsibility more flexible,and gives full play to the role of functional departments, ensures coordination among organizations, information processing and short path of instruction transmission, under the premise that the project manager has the most control over the project.

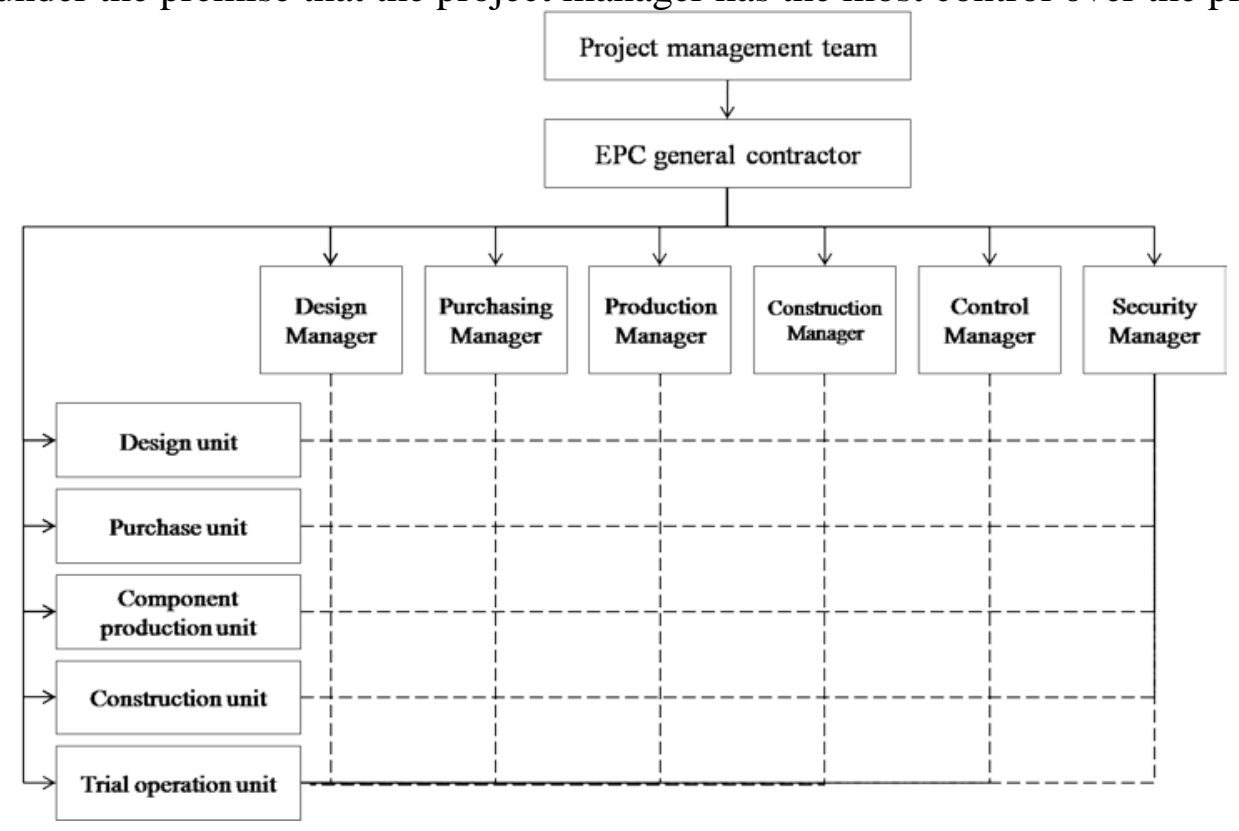

Figure 1 organization structure of EPC integrated matrix

The project management team is composed of all participants in the project. It is combined dynamically by design tasks and works cooperatively ${ }^{[6]}$. The combination of project management draws on the management experience of different participants at the early stage of design, takes full consideration of the factors that affect the project and reduces the risk of engineering change. And, in the organization mode of project management team, different participants have same interests and objectives, and the team work and organization cooperation will be stronger.

ERP is an online commmunication platform which provised the information in the project the participants need, based on the integration, storage and management of information and data provided by participants in the project. It is mainly used to provide a platform to share and communicate for participants in the project and create coorporate atmosphere, the engineering information portal provides integrated information and communicate method.

\subsubsection{Process optimization}

The work flow of industrialized building is decomposed and restructured based on the modular and group technology (GT) of manufacturing industry. According to the idea of modularization, the project can be decomposed into middle module which can be quickly assembled together; according to the principle of process, a group of similar process is generated to obtain a high efficiency of mass production. The work flow model of industrialized buildings project is presented in Figure 2.

\section{(1) Project decomposition}

In design phase, with the help of BIM and other building information model software, according to the correlation of the building structure, taking sub assembly such as integer bathroom, integer 
kitchen, standard components as guidance, the project can be decomposed into several modules which can be transported and assembled.

\section{(2) Technology decomposition and reorganization}

Decomposing the project modules according to different technology, the units with the same process are grouped together to form a working package. Making full use of GT to maximize production efficiency. In this process, the elements of the decomposition are encoded, such as the a1 in figure 2 represents the process 1 unit in the module unit a.

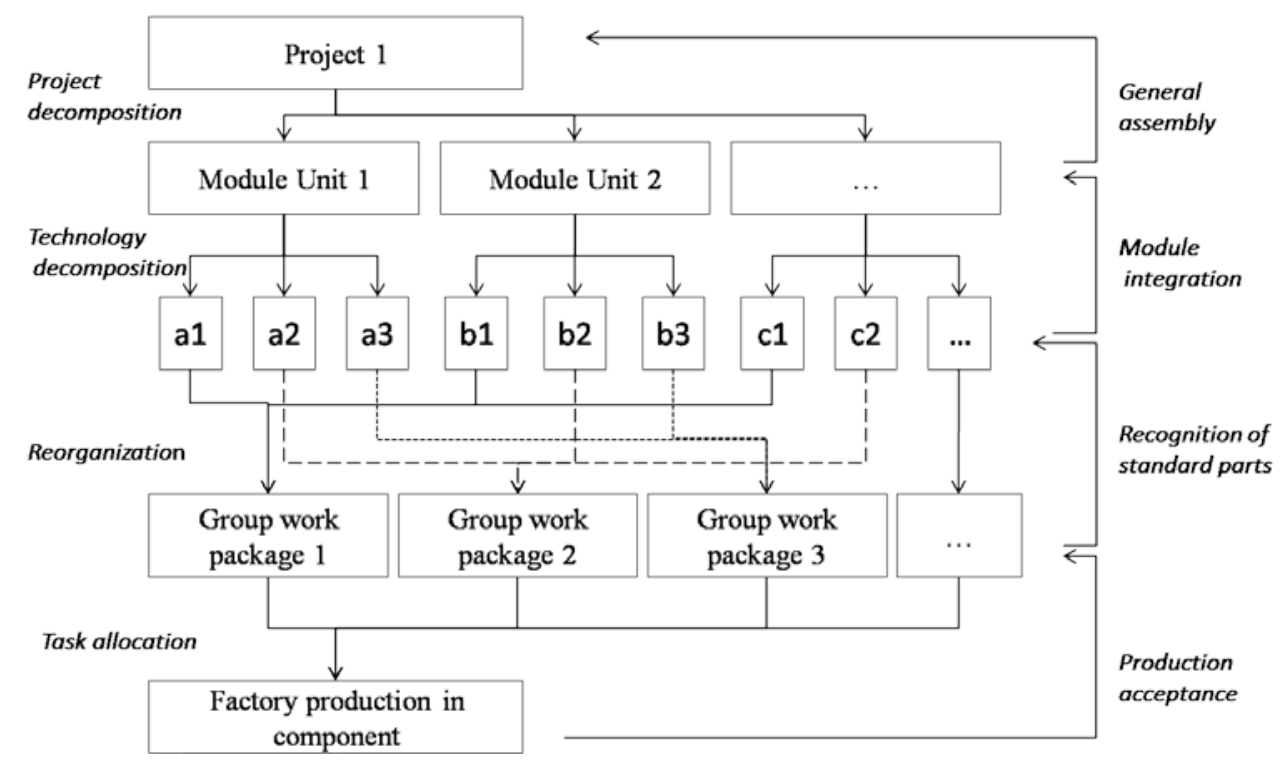

Figure 2 The work flow model of industrial construction project

\section{(3) Task allocation}

After the formation of group work package, the appropriate component manufacturers should be chosen for production. After the formation of social industry chain, the module production will be carried out in the form of outsourcing.

\section{(4) Productions acceptance and recognition}

After completing the production of component units, the relevant standards are needed;

And the standard units are identified by the coding system and assigned to different module assembly groups.

\section{(5) Module integration}

Module assembly group assembles the module units according to the coding information to form a sub assembly for transportation and assemblage.

\section{(6) General assembly}

Assemble all modules on site.

\subsubsection{Realization of information integration}

Information integration of project management in industrialized buildings is the basis for the organization optimization and process optimization. Information integration model mainly consists of four parts: information exchange platform, business information management platform, communication network infrastructure platform and project database. Its main function is exchanging project information, supporting management decision, collecting project information and manafing project data. Information integration model is formed by unified central database and a number of communications network infrastructure, relies on modern computer and information processing technology. 


\subsection{Difficulties in implementing EPC general contracting model in industrialized buildings}

\subsubsection{Laws and regulations}

In China, the engineering general contract and the laws and regulations in construction are not very sound. There are some problems in the tax system, the bidding management method, and so on. In taxation, general contractor and owner tend to sign one contract, or the design, procurement and construction are respectively displayed in the general contracting contract. The contract signed in this way is faced with the risk of being paid double taxes which are VAT and business tax by the tax bureau. In addition, the bidding regulation in industrialized buildings is still not perfect, many projects follow the traditional bidding regulation and it indirectly causes the increasing cost of management, confusing responsibility, and many other problems. Standard system, laws and regulations related to industrialized buildings are still in the process of improving, such as the lack of quality inspection method of concrete component at the national level. The imperfection of laws, regulations and standards system directly impact the implementation of EPC general contract model in the industrialized buildings.

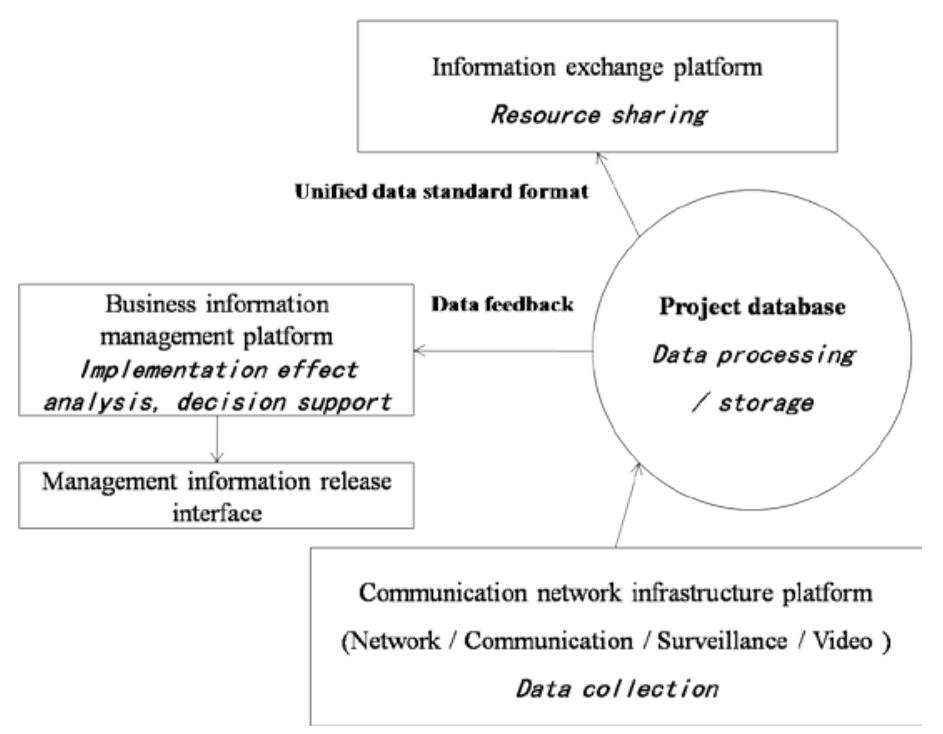

Figure 3 Information integration model

\subsubsection{The capability of enterprise}

The EPC enterprises should accelerate the transformation and upgrading of comprehensive ability, strengthen design and construction integration, civil and decoration integration, construction management information and other capacity and mechanism construction.

But in the design and construction integration, at present due to the development of domestic market, the barriers of qualification and other reasons, few general contractors can obtain relevant qualifications at the same time, so the companies have to combine construction companies into a combo or subcontracting the work to the units with relevant qualification. There will be some problems in it. For example, design enterprises are general lack of experience in construction and project management, and the problem of construction companies' management not reaching the designated position is easy to come.

In the civil and decoration integration, subject general contracting and professional subcontractor coordination does not reach the designated position. Appropriate method which is used to strength the contact with professional subcontracting is lacked in design phase, and the specialized subcontracting is not taken so much considerations ${ }^{[9]}$.

\subsubsection{The problems of managers' personnel quality}

The lack of talent has been one of the major issues affecting the development of general contracting and project management in China. In conclusion, the problems of managers' personnel quality in our country mainly embodied in the following aspects: lacking the knowledge of 
construction industrialization and EPC, whole life cycle management; management experience of the industrialized buildings projects and the EPC project.

\subsection{Policy suggestions}

An appropriate industry management mode should be established adapted to the development of the construction industry modernization. Promote and implement the management of EPC, improve the market access system and bidding system, create the market environment conducive to the development of construction industrialization. The government needs to improve the project cost management system, establish the construction quota system adapted to the industrialized buildings, formulate rating and pricing specification of bill of quantities for prefabricated construction, develop the construction drawing design review system and related technical audit points for the prefabricated building, make the depth of project design meet the requirements of production in factory and assembly on site. Establish the acceptance filing system of construction industrialization, in the stage of completion inspection and acceptance for the record, documents of precast rate, assembly rate, implementation area of industrial and so on should be presented. Statistical system of construction industry modernization should be established based on the database of enterprises and projects developed by current information. The vertical and horizontal construction alliance of industry modernization should be encouraged to build, and optimize the allocation of resources, collaborative innovation and entrepreneurship, to achieve the overall leap forward development. Establish a sound construction industrialization general contracting management system should be established and the abilities of relevant enterprises should be developed.

\section{Acknowledgement}

Subject "Research on green house standards and different constructions' standards in different regions" (2012BAJ10B01) sponsored by Ministry of Science and Technology "Twelfth Five". Subject "Research on installation key technology and scale application demonstration" (2011BAJ10B06) sponsored by Ministry of Science and Technology "Twelfth Five". Subject "Research on collaborative innovation mechanism construction industrialization among stakeholders: Based on dynamic social network” (71401002) sponsored by national natural science foundation of china. Subject "Comparative Analysis of Applicative Technology in Construction Industrialization at home and abroad”(2014-2015)sponsored by Ministry of Housing and Urban-Rural Development. Subject "Research on Annual Report of Development in Construction Industry Modernization”(2015)sponsored by Ministry of Housing and Urban-Rural Development. Subject“ Establishing Visible Coorporate Working Platform Used to Simulate Construction in Industrialized Building”(PXM2015_014212_000063) sponsored by Beijing Municipal Commission of Education. Subject" Establishing Simulation Experiment Platform for Construction Project Management ”(PXM2015_014212_000065)sponsored by Beijing Municipal Commission of Education.

\section{References}

[1] Yingbo Ji: Research on the production mode of new-type construction industrialization in China ( Residential Industry, 2011)

[2] Chengwen Wang: Research on the mode of modern shipbuilding (doctoral dissertation, 2006)

[3] Yu Liu, Zhongfu Li. Research on the establishment of organizational system in construction industrialization -based on the theory of modern manufacture (Construction Economy, 2014)

[4] Lihua Zhan. Application of EPC in hydraulic engineering (doctoral dissertation, 2010)

[5] Huijun Liu. The Advantages of EPC (China Science and Technology Information, 2014) 
[6] Hongliang Zhang, Zhanwen Niu. Extension of Lean Production-Lean Design (Science and technology management research, 2010)

[7] Fengping Yu, Hongjun Xiao, Zhaohua Jiang. Analysis on Comprehensive Innovation Strategy in Modern Production Mode (Journal of Dalian University of Technology Social Science, 2010)

[8] Hongmei Shi. Tax revenue risk in the mode of EPC (Fiscal and Financial, 2015)

[9] Jianjun Cai. Research on Construction Subcontract Risk Management of General Contractor Enterprise in Construction Engineering (City Construction, 2015) 